\title{
Reversing Early Stage Prostate Cancer in a Hypertensive Patient: A Case Study on Nutritional Cum Phyto-Therapy
}

\author{
Steve Yap
}

DSY Wellness \& Longevity Center, Kuala Lumpur, Malaysia

\begin{abstract}
While prostate cancer is the most common male malignancy in the West, it is ranked as the number two cancer death for non-smokers in many developing countries. This case study demonstrates how an early stage prostate cancer might be treated by a comprehensive and evidence-based nutritional cum phytotherapy if patient is given the option of using it. According to the ANMP (www.anmp.org.my), a nutritional therapy is used to treat, control, or prevent chronic disorders by impacting on the hormonal, neurological, and immune functions of the patient. It may take a decade or longer to develop a malignancy. Three quarter of prostate cancer occurs in men over fifty five years when they go through andropause, which is evidenced partly by elevation in their oestrogen levels. However, being overweight or obese may trigger early progression of prostate cancer in men.
\end{abstract}

Keywords: Prostate cancer, dietary/lifestyle modifications, nutritional cum phyto-therapy, andropause, prostate specific antigen, metastasis.

\section{CASE PRESENTATION}

Jonathan M., age 46, a United States citizen who was working as a senior engineer with an oil corporation based in South East Asia. Two months' ago, he was diagnosed at a San Francisco men's clinic as having stage $B$ prostate cancer. A digital rectal examination (DRE) was done after his serum Prostate Specific Antigen (PSA) shown a score of $9.3 \mu \mathrm{g} / \mathrm{L}$. A subsequent needle biopsy confirmed his prostate malignancy although there was no evidence of metastasis. His employers in Jakarta, Indonesia recommended him to seek natural therapy(ies) at the DSY Wellness Center in Kuala Lumpur instead of the invasive treatment at a conventional medical center.

Besides on hypertensive drug for the past two years, the patient did not notice any major symptoms. However, he had nocturia, dribbling after urination, problems in the initiation and cessation of urination, occasional burning sensation during urination, and some chronic pain from his lower back and hips. Like most of his siblings, he was overweight for most part of his life. But he did notice that he was losing weight during the past three years. His father was diagnosed with prostate tumor at aged 51, whereas his mother was diagnosed with ovarian tumor during her late 30's.

The patient was not offered any advice on dietary and lifestyle changes to improve on his conditions after his adenocarcinoma was confirmed by an oncologist. Consequently, he continued his smoking and drinking habits.

*Address corresponding to this author at the DSY Wellness \& Longevity Center, Kuala Lumpur, Malaysia; Tel: +60342701266;

Fax: +60342701831; E-mail: dsy@dsywellness.com
The lifestyle modifications recommended to this patient included:

(a) Moderate exposure to morning sunlight: Those living in sunny areas [1] and men with a history of exposure to high levels of sunlight [2] have lower risk of prostate cancer. Sunshine exposure causes cholesterol to be used to generate Vitamin D3, which improves the prognosis of prostate cancer patient [3] while it prevents progression of malignancy [4]. Men with vitamin D as measured by $25(\mathrm{OH}) \mathrm{D}$ levels below 16 $\mathrm{ng} / \mathrm{mL}$ might suffer some $70 \%$ higher incidence rate of prostate cancer than those with levels above $16 \mathrm{ng} / \mathrm{mL}$. Even younger men with 25 $(\mathrm{OH}) \mathrm{D}$ levels below $16 \mathrm{ng} / \mathrm{mL}$, their incidence of prostate cancer could be 3.5 -fold higher than for those with levels of $16 \mathrm{ng} / \mathrm{mL}$ or above and incidence of invasive cancer could be 6.3-fold higher [5]. However, not all studies found such a strong association [6]. Those with darker skin do require longer sunlight exposure to generate the same levels of $25(\mathrm{OH}) \mathrm{D}$ compared to individuals with lighter skin tone.

(b) Exercising: 30 minutes a day of moderate exercise such as walking could be healthful. Obesity elevates risk of developing prostate cancer. Body mass index (BMI) greater than 30 may carry 1.27-fold higher risk of developing and dying from the disease than non-obese men [7]. Furthermore, men with the highest waist-to-hip ratios might be $300 \%$ more likely to develop prostate cancer as those with the smallest waistto-hip ratios [8]. Obesity is also associated with 
more aggressive and late-stage prostate tumours [9].

The patient was advised to temporarily avoid:

(i) Calcium: Men on this supplement might increase their risk of prostate cancer [10].

(ii) Cooking oils which oxidize easily such as those from corn and sunflower - both of which are rich in linoleic acid (omega-6) - stimulate growth of prostate cancer cells called DU145 [11]. Even high intake of alpha-linolenic acid (canola, soy, and flax seed oils) might increase risk of developing prostate cancer [12].

(iii) Smoking: Men with prostate cancer who smoke tend to have poorer treatment outcomes than those who do not smoke [13].

(iv) Alcohol: Up to 22 alcoholic drinks per week can raise risk of progressing prostate cancer [14].

Since many cancer patients die from malnutrition created by their cancer progression, a comprehensive dietary plan consisting of these food items were recommended:

(a) Fatty fish: Increased intake of eicosapentaenoic acid (EPA) and docosahexaenoic acid (DHA) decrease risk of developing prostate cancer, in general, and reduce risk of developing advanced stage disease in those already with prostate cancer [15]. It can inhibit the conversion of testosterone to dihydrotestosterone (DHT), which may be a factor in the development and progression of prostate cancer [16]. Fish rich in EPA/DHA include mackerel, cod, anchovy, and wild salmon.

(b) Nuts and seeds: In raw form, they are a rich source of monounsaturated fats and vitamin $E$ helpful to prostate cancer patient. Brazil nuts, for instance, may contain as much as 544 micrograms of selenium per ounce [17]. Just two Brazil nuts provide some $200 \mathrm{mcg}$ selenium sufficient to lower this cancer risk [18] while offering $50 \%$ reduced risk of cancer death [19].

(c) Organic leafy vegetables, citrus and berries: The American National Cancer Institute recommends the ingestion of at least five servings daily of fruits and vegetables to fight the development and progression of prostate cancer [20]. These foods contain anti-carcinogenic compounds such as chlorophyll, carotenoids, flavonoids, indole, polyphenols, sulforaphane, and protease inhibitors [21]. Although vitamin C intake from foods alone does not clearly appear to reduce rate of prostate cancer [22], several studies have linked higher dietary vitamin $\mathrm{C}$ intake with overall reduced risk of cancer including prostate [23-26]. Richest food sources of vitamin C include chilli, guava, bell pepper, green kiwi, and berries. Carotenoids and retinoids (pro-vitamin A) from say papaya and pumpkins could lower the incidence or preventing the occurrence of prostate cancers [27].

(d) Lycopene-rich food: A diet high in tomatoes might offer $50 \%$ reduced incidence of cancer [28]. Lycopene lowers prostate cancer risk [2932], enhances the level of apoptosis (programmed cell death) of prostate cancer cells [33] or inhibits its growth [34,35] while showing strong antioxidant activity [36] in prostate cancer patients. Lycopene is also found in carrots, green peppers, apricots, pink guava, watermelon, and pink grapefruit. Even frequent use of tomato sauce or paste is associated with a decreased risk of prostate cancer development $[37,38]$. As a fat soluble carotenoid, lycopene is a precursor of beta-carotene [39] but possesses at least twice the antioxidant capacity of betacarotene [40]. When combined with food rich in vitamin $E$, it down regulates the levels of 5alpha-reductase, an enzyme involved in the possible progression of prostate cancer [41].

(e) Spices: These add flavour to food and also possess cancer-fighting properties. Those with strong anti-carcinogenic activity include garlic and ginger [42], as well as turmeric [43-45] which contains curcumin that inhibits cancer at its initiation, promotion and progression stages of development [46]. It is a cyclooxygenase2(COX2)-inhibitor and it possesses both antiinflammatory and antioxidant properties which inhibit prostate cancer growth by making natural cancer-fighting processes within the cell more effective [47]. It inhibits metastasis of prostate cancer to the bones [48]. It increases susceptibility of prostate cancer cells to any radiation therapy [49]. It is able to affect gene transcription and to induce tumour cell apoptosis [50]. Curry powder also contains a fair amount of genistein and other phytonutrients. Hot chilli 
contains capsaicin, which has anti-tumour effects too [51].

(f) Yellow or green Tea (Chinese or Japanese): This beverage reduces the risk of prostate cancer [52,53] and prevents development of tumors by blocking angiogenesis (growth of new blood vessels) [54]. It inhibits activity of 5-alphareductase, the enzyme that converts testosterone to dihydrotestosterone (DHT), which has carcinogenic effects in the prostate [55] as well as other enzymes associated with the growth of prostate cancer cells [56]. Its most abundant and active polyphenol is epigallocatechin 3-gallate (EGCG) [57], which inhibits prostate cancer cells from multiplying $[58,59]$ and promoting their destruction [60]. It also inhibits the activity of the enzyme proteasome, a key factor in the formation of prostate cancer [61] and the enzyme COX-2 involved in the progression of prostate cancer [62].

EGCG induces apoptosis and alters the expression of cell cycle regulating proteins that are critical for cell survival and apoptosis $[63,64]$. It has anticancer activity in patients with androgen-independent prostate carcinoma [65].

(g) Soy: Intake of soy products is associated with a lower incidence of oestrogen-related cancers such as prostate $[66,67]$. Men with the highest consumption of tofu may have the lowest risk of developing prostate cancer $[68,69]$. Other valuable sources of soy include soy isolate, soy protein, fujuk, tempeh, soy flour, soy milk, and miso. The Protein Digestibility Corrected Amino Acid Score (PDCAAS) adopted by the USA-FDA and World Health Organization show soy isolate as having the same quality protein as egg white and human milk protein [70]. Saponins in soy beans possess a variety of anti-cancer properties [71]. Phytates or phytic acid (IP6) in soy increases natural killer cell activity in the body [72] while its phytoestrogens have antiestrogenic effects [73] and 5-alpha reductase reduction activity [74]. Dietary concentrations of genistein, which is a natural protein tyrosine kinase (PTK) inhibitor, could stop prostate cancer cell metastasis [75] via cell detachment and cell invasion [76]. PTK inhibition is major factor in the inhibition of cancer [77]. (h) Berries and citrus fruits: Consuming myricetinrich berries can lower rates of prostate cancer [78]. Myricetin has antioxidant properties and its richest food sources per 100 grams are blueberries $(2.66 \mathrm{mg})$, blackberries $(0.67 \mathrm{mg})$, and cranberries $(6.78 \mathrm{mg})$. Red onions and walnut are also a rich source.

The nutritional supplements prescribed for this patient were:

(i) Zinc citrate (32\% elemental zinc): $40 \mathrm{mg}$ twice a day equivalent to $25 \mathrm{mg}$. This mineral inhibits the enzyme 5-alpha-reductase activity, which reduces the conversion of testosterone to DHT $[79,80]$. It prevents the specific binding of androgens to nuclear and cytosol androgen receptors [79]. Zinc is absolutely vital to the apoptosis of prostate cancer cells through its effects on the compound known as fetuin [81]. It also regulates tumor cell invasion of other tissues in the prostate [82]. Zinc inhibits prolactin secretion by the pituitary gland $[83,84]$. Increased prolactin secretion leads to higher levels of DHT [85].

(ii) Vitamin D: 2,000 IU of this vitamin three times a day may be helpful for treating prostate cancer [86] since these cancer cells lack a component of vitamin $D$ that is typically present in healthy prostate cells [87]. It inhibits prostate cancer cell growth or proliferation $[88,89]$ via a number of cellular pathways, including cell cycle arrest, induction of apoptosis, and altered activation of growth factor signalling [90]. However, vitamin D metabolites produce inhibitory effects on specific receptors in prostate cancer cells [91]. It also protects non-malignant prostate epithelial from oxidative stress-induced cell death [92].

(iii) Soy isoflavones (standardized to $25 \%$ genistein): $500 \mathrm{mg}$ three times a day. Just $60 \mathrm{mg}$ daily could moderately reduce PSA levels [93]. Lower intake of genistein is associated with higher rates of cancer [94]. It is a strong inhibitor of angiogenesis, which is a major factor in the growth of cancer cells [95]. Besides, it induces tumour cell apoptosis [96]. Isoflavones inhibits many different prostate cancer cell lines, but its daidzein component may not have the same effect [97]. Just three weeks' therapy could result in increased antioxidant activities resulting in inhibition of prostate cancer cell formation [98]. 
Even low doses of its genistein can induce apoptosis in prostate cancer cells [99]. Genistein and daidzein counteract the negative effects of DHT on the prostate gland and its cancer cells [100].

(iv) Selenium yeast: $350 \mathrm{mg}$ once a day (equivalent to $150 \mathrm{mcg}$ elemental selenomethionine) since the patient included some mixed nuts in his diet. Selenium deficiency increases the risk of cancer [101] and is associated with an increased risk of fatal cancer [102]. This micro-nutrient could reduce prostate carcinoma cell growth by $50 \%$ [103]. It plays a key role in the induction of apoptosis of prostate cells [104]. Higher levels of selenium counteract the prostate cancer cellstimulatory effects of cadmium in vitro [105]. Apparently, selenium destroys prostate cancer cells by interfering with the metabolism of a compound called 5-lipoxygenase that is critical to its growth [106]. The combination of selenium and vitamin $E$ can offer additive effects on the destruction of enzymes important in the progression of prostate cancer [107]. While supplementation can reduce cancer risk [108], serum selenium levels higher than $150 \mathrm{ng} / \mathrm{mL}$ may negatively affect patient's mortality rate [109].

(v) Mixed tocopherols: 400 IU twice a day. Natural vitamin $\mathrm{E}$ supplementation can significantly reduce risk of developing prostate cancer [110113]. D-alpha-tocopherol, when combined with lycopene, inhibits prostate cell proliferation [114] although when consumed individually gammatocopherol might be more effective [115]. The inhibitory effects on prostate cancer cells are likely to be linked to its androgen suppression [116].

Additionally, these herbal extracts were prescribed:

(a) Serenoa repens extract: $500 \mathrm{mg}$ three times a day. This oily palm extract inhibits the conversion of testosterone to DHT in the prostate [117]. It has anti-estrogenic and receptor site-binding effects too [118]. Recent research suggests that estrogen strongly contributes to prostate cancer partly because this hormone reduces the ability of the prostate gland to clear its DHT levels. Serenoa repens extract for 90 days can result in lower receptor values for estrogen [117]. It significantly improves symptoms such as dysuria, nocturia, prostate volume, and residual urine $[119,120]$. It also reduces the expression of cyclooxygenase-2, a newly recognized factor in the development of prostate cancers [121]. Although Silybum marianum inhibits conversion of testosterone to DHT [122], the patient did not also suffer from sluggish liver to justify its use.

(b) Panax Ginseng (standardized to $60 \%$ ginsenosides): $400 \mathrm{mg}$ thrice a day. Ginsenoside Rg3 inhibits growth of prostate carcinoma cell line [123].

(c) Annona muricata leaf tea: $1 \mathrm{~g}$ three times a day. Its leaf contains compounds which might be selectively cytotoxic to prostate cell line (PC-3). Prostate cancer cell toxicity is estimated to be between 10 and 100 -fold the potency of the chemotherapy drug Adriamycin [124]. Other study suggests a potency of up to 10,000 times compared to this drug [125].

(d) Pygeum (standardized to $14 \%$ triterpenes including betasitosterol and $0.5 \% \mathrm{n}$-docosanol): $1 \mathrm{~g}$ three times a day. This seed inhibits the progression of both prostate cancer and benign prostate hyperplasia [126]. It can induce prostate cancer cell apoptosis [127]. Like Serenoa repens, it improves a variety of urinary symptoms such as urinary frequency, nocturia, flow interruption, after-dribbling, weak stream, and hesitation [128]. Additionally, pygeum increases prostatic secretions and improve the composition of the seminal fluid [129], besides raising patient's capacity to achieve erections [130].

(e) Artemisia (standardized to $25 \%$ artemisinin): $500 \mathrm{mg}$ three times a day. It can act as an oxidant that selectively destroys cancer cells when it interacts with the mineral iron [131]. Cancer cells contain up to 1,000 times more iron than normal cells. Artemisinin and transferrin (stored iron) might be some 34,000 times more effective in selectively killing cancer cells than normal cells [132].

\section{BENIGN PROSTATE HYPERPLASIA (BPH)}

$\mathrm{BPH}$ and prostate cancer are not the same condition and they develop in different parts of the prostate gland. However, both conditions produce elevated PSA levels and a variety of urinary problems. 
In addition, both are considered hormonally-related disorders. BPH occurs in more than $50 \%$ of all men in their 60 s and in as many as $90 \%$ of men in their 70 s and 80 s. Like prostate cancer, BPH may be promoted by the relatively increased levels of estradiol (E2) that occur in men as they age. Intake of more than 25 ounces per month of alcohol is correlated with the development of BPH [133] since alcohol is estrogenic. The mean prostate zinc tissue content may be significantly lower in BPH patients [134]. Serenoa repens [135 [136] and soy phytoestrogens [137] are also effective in treating symptoms of BHP.

\section{DIAGNOSTIC ISSUES}

The prostate is a walnut-sized gland located beneath the bladder of males and it surrounds the upper part of the urethra, which is the tube that carries urine from the bladder. The digital rectal examination once the "gold standard" - is being superseded by techniques such as serum and tissue-based assays [138]. Molecular markers for prostate cancer such as DNA ploidy and nuclear morphometry were considered unnecessary for the patient, who came with full biopsy and other relevant reports issued by reputable hospitals.

While the incidence of prostate cancer in Asians seems to be the lowest [139], it is the most common male malignancy in the Western world but with rather ill-defined risk factors [140]. Some $75 \%$ of prostate cancers occur in individuals 55 years of age and older [141]. Other sources confirm that $60 \%$ of all prostate cancer cases are diagnosed in men 65 years of age and older [142,143]. Related risk factors include race and geography [144].

Consequently, the patient's family history and dietary/ lifestyle habits could play a crucial role in both the initiation and development stages of his cancer. Indeed, studies found significant association of HPC2 genotypes with prostate cancer [145,146], whereas some studies found no significant association between them [147,148]. A man whose father had prostate cancer may be $230 \%$ more likely to develop the disease than if his father never had the disease. A man is also more likely to develop this cancer if his sister or mother develops breast or ovarian cancer. Some 15\% of inherited cases may be transmitted through the mother's chromosome. A different gene called HPC1 has been associated with about $30 \%$ of all inherited cases of prostate cancer. The highly expressed AP-N in human cancerous prostate probably plays an important role in the invasion and metastasis of prostate cancer cells [149]. Furthermore, childhood obesity is associated with an increased risk of prostate cancer late in life [150].

Between $50 \%$ and $90 \%$ of all cancers may be prevented with proper nutrition [151]. However, carcinogens exist in modern diet including those found in fruits and vegetables. Strawberry, for instance, has some of the highest pesticide content compared to other imported fruits. Cadmium toxicity, say from cigarette smoke, as a risk factor could be assessed from the patient's urine [152]. However, urine testing for this heavy metal was unavailable locally.

Adenocarcinoma is the primary type of prostate cancer. Prostate function is regulated by the male hormone testosterone, which can be converted to DHT due to zinc deficiency. Toxic chemicals such as dioxin [153] and pesticides from fruits and vegetables can increase the converting activity of 5-alpha reductase. Blocking this enzyme may diminish the development of prostate cancer [154] since DHT is essential for prostate cell differentiation [155]. Available evidence suggests that prostate cancer could not be considered solely in terms of its response to androgens [156].

There is now a body of research that links prostate cancer to increased exposure to oestrogen [157-159]. In the United States, a link was found between prostate cancer and the oral conceptive by-products found in drinking water [160]. However, other studies did not find such a clear association $[161,162]$.

Since cancer mortality is directly proportional to disease stage, the detection of stage 2 rather than endstage prostate cancer offers a longer survival opportunity for the patient [163].

Till his posting to South East Asia, the patient spent mainly indoor with little sunlight exposure. Vitamin D deficiency is an important factor in the development of prostate cancer [164]. Being overweight, the patient would need longer exposure to sunlight compared to non-overweight individuals since most of this fat soluble vitamin could be stored in his adipose tissues and unavailable for his use [165].

Prostate enlargement such as $\mathrm{BPH}$ as well as infections can mimic some of the symptoms of cancer. Consequently, prostate cancer can develop with no significant symptoms, particularly in its early stages. As the disease progresses, however, the symptoms might include frequent urination particularly at night, inability 
to urinate, painful urination, problems with cessation of urination, blood in urine, pain in ejaculation, and persistent pain in the upper thighs, lower back or hips.

Based on decades' long understanding that cancer cells feed on sugar, the PET imaging offers the potential to detect malignant cells based on their increased glucose metabolism wherever they are located within the body [166]. However, this was considered unnecessary since the adenocarcinoma was adequately documented.

Radioimmunoassay analysis of PSA may be used for diagnosing both localized as well as metastasized stages of the prostate cancer. Though controversial, PSA is nevertheless the most sensitive marker for monitoring this disorder and it is elevated in $25 \%$ to $92 \%$ of patients with prostate cancer. However, it is also raised in $30 \%$ to $50 \%$ of men with $\mathrm{BPH}$ or prostatitis (inflamed prostate gland). The patient was not offered the newer ultrasound technique using the Doppler, which along with targeted biopsy, seem to have a detection rate some two-fold higher than systematic biopsy $[167,168]$. It reduces the need for repeated biopsies since the colour Doppler imaging can determine the staging of high-grade prostate cancer [169] and it permits tracking of changing prostate conditions over time [170]. Prostate cancer, if unsuccessfully untreated, can lead to osteoblastic bony metastases. Bone scans or $\mathrm{x}$-rays were considered unnecessary in this case since there was no evidence of the cancer metastasizing.

Malnutrition is a common problem among most cancer patients and any cachexia is associated with rather poor response to further therapy [171]. Extracts from the patient's blood tests and physical statistics for the first three months' therapy during the year 2011 were as follow:

\begin{tabular}{|c|c|c|c|c|}
\hline & April $^{*}$ & May & June & July \\
\hline \multicolumn{5}{|l|}{ Serum } \\
\hline 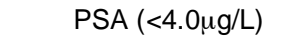 & 9.6 & 8.1 & 5.8 & 3.2 \\
\hline Hs-CRP (<1.0mg/L) & 25.3 & 20.6 & 13.9 & 6.4 \\
\hline $\mathrm{TG}(<200 \mathrm{mg} / \mathrm{dl})$ & 310 & 288 & 237 & 187 \\
\hline $\mathrm{HbA} 1 \mathrm{c}(\sim 5 \%)$ & 6.5 & 6.2 & 5.9 & 5.8 \\
\hline Selenium (ng/mL) & 116 & 118 & 122 & 127 \\
\hline $25(\mathrm{OH}) \mathrm{D}(\mathrm{ng} / \mathrm{mL})$ & 12 & 13 & 18 & 22 \\
\hline
\end{tabular}

\begin{tabular}{|c|c|c|c|c|}
\hline \multicolumn{5}{|l|}{ Physical: } \\
\hline BMI & 31.5 & 29.7 & 28.4 & 26.2 \\
\hline Skeletal muscle\% & 28.9 & 31.5 & 31.7 & 32.6 \\
\hline VFA\% & 19 & 17 & 16 & 14 \\
\hline Total body fat\% & 33.5 & 31.3 & 29.6 & 28.2 \\
\hline Total body water\% & 44.2 & 47.3 & 49.1 & 51.6 \\
\hline Blood pressure (S/D) & $142 / 91$ & $138 / 88$ & $136 / 86$ & $131 / 85$ \\
\hline
\end{tabular}

*date of first consultation.

Although during August 2011 a major private hospital in Singapore declared the patient free from prostate cancer, he continued with his nutritional therapy for another three months. He was advised to recheck his conditions when he returned to San Francisco in November that year.

With dietary and lifestyle modifications, his blood pressure was moderately lowered at the end of his third month of therapy. He was advised not to stop his medication without consultation with his prescribing physician.

\section{CONCLUSION}

The outcome achieved at the end the fourth month strongly suggests that a well-designed, comprehensive nutritional cum phyto-therapy could halt or even reverse prostate cancer especially in its early stages. However, it was unclear if such a natural therapy could reverse or control advanced stage prostate cancer.

\section{REFERENCES}

[1] Hanchette C, Schwartz G. Geographic patterns of prostate cancer mortality. Evidence for a protective effect of ultraviolet radiation. Cancer 1992; 70: 2861-9.

http://dx.doi.org/10.1002/1097-

0142(19921215)70:12<2861::AIDCNCR2820701224>3.0.CO;2-G

[2] Luscombe CJ, Fryer AA, French ME, et al. Exposure to ultraviolet radiation: association with susceptibility and age at presentation with prostate cancer. Lancet 2001; 358(9282): 641-2.

http://dx.doi.org/10.1016/S0140-6736(01)05788-9

[3] Robsahm TE, Tretli S, Dahlback A, Moan J. Vitamin D3 from sunlight may improve the prognosis of breast-,colon-, and prostate cancer (Norway) 2004. Cancer Causes Control 2004; 15: 149-58. http://dx.doi.org/10.1023/B:CACO.0000019494.34403.09

[4] Bao BY, Ting HJ, Hsu JW, Lee YF. Protective role of 1 alpha, 25-dihydroxyvitamin D3 [vitamin D3] against oxidative stress in non-malignant human prostate epithelial cells. Int $\mathrm{J}$ Cancer 2008; 122: 2699-706.

http://dx.doi.org/10.1002/ijc.23460

[5] Ahonen MH, Tenkanen L, Teppo L, Hakama M, Tuohimaa P. Prostate cancer risk and prediagnostic serum 25hydroxyvitamin D levels (Finland). Cancer Causes Control 2000; 11: 847-52.

http://dx.doi.org/10.1023/A:1008923802001 
[6] Tuohimaa P, Tenkanen L, Ahonen M, et al. Both high and low levels of blood vitamin $D$ are associated with a higher prostate cancer risk: a longitudinal, nested case-control study in the Nordic countries. Int J Cancer 2004; 108: 104-8.

http://dx.doi.org/10.1002/ijc.11375

[7] Rodriguez C, Patel AV, Calle EE, et al. Body mass index, height, and prostate cancer mortality in two large cohorts of adult men in the United States. Cancer Epidemiol Biomarkers 2001; 10: 345-53.

[8] Hsing AW, Deng J, Sesterhenn IA, et al. Body size and prostate cancer: a population-based case-control study in China. Cancer Epidemiol Biomarkers Prev 2000; 9: 1335-41.

[9] Putnam SD, Cerhan JR, Parker AS, et al. Lifestyle and anthropometric risk factors for prostate cancer in a cohort of lowa men. Ann Epidemiol 2000; 10: 361-9.

http://dx.doi.org/10.1016/S1047-2797(00)00057-0

[10] Giovannucci E, Rimm EB, Wolk A, et al. Calcium and fructose intake in relation to risk of prostate cancer. Cancer Res 1998; 58: 442-7.

[11] Connolly JM, Coleman M, Rose DP. Effects of dietary fatty acids on DU145 human prostate cancer cell growth in athymic nude mice. Nutr Cancer 1997; 29: 114-9.

http://dx.doi.org/10.1080/01635589709514611

[12] Brouwer IA, Katan MB, Zock PL. Dietary alpha-linolenic acid is associated with a reduced risk of fatal coronary heart disease, but increased prostate cancer risk: a meta-analysis. J Nutr 2004; 134: 919-22.

[13] Chyou PH, Nomura AM, Stemmermann GN, Hankin JH. A prospective study of alcohol, diet, and other lifestyle factors in relation to obstructive uropathy. Prostate 1993; 22: 253-64. http://dx.doi.org/10.1002/pros.2990220308

[14] De Rosa G, Corsello SM, Ruffilli MP, Della Casa S, Pasargiklian E. Prolactin secretion after beer. Lancet 1981; 2: 934.

http://dx.doi.org/10.1016/S0140-6736(81)91422-7

[15] Leitzmann MF, Stampfer MJ, Michaud DS, et al. Dietary intake of $n-3$ and $n-6$ fatty acids and the risk of prostate cancer. Am J Clin Nutr 2004; 80: 204-16.

[16] Pham H, Ziboh V. 5-alpha-reductasecatalyzed conversion of testosterone to dihydrotestosterone is increases in prostatic adenocarcinoma cells: suppression by lipoxygenase metabolites of gamma-linolenic and eicosapentaenoic acids. J Steroid Biochem Mol Biol 2002; 82: 393-400. http://dx.doi.org/10.1016/S0960-0760(02)00217-0

[17] U.S. Department of Agriculture, Agricultural Research Service. 2011. USDA National Nutrient Database for Standard Reference, Release 24. Nutrient Data Laboratory Home Page, http://www.ars.usda.gov/ba/bhnrc/ndl. Accessed: May 23, 2012.

[18] Schrauzer G. The nutritional significance, metabolism and toxicology of selenomethionine. Adv Food Nutr Res 2003: 47: 73-112. http://dx.doi.org/10.1016/S1043-4526(03)47002-2

[19] Clark LC, Combs GF Jr, Turnbull BW, et al. Effects of selenium supplementation for cancer prevention in patients with carcinoma of the skin: a randomized controlled trial. Nutritional Prevention of Cancer Study. JAMA 1996; 276: 1957-63.

http://dx.doi.org/10.1001/jama.1996.03540240035027

[20] Zigler R. Vegetables, fruits, and carotenoids and the risk of cancer. Am J Clin Nutr 1991; 53: 2515-95.

[21] Waladkhani A, Clemens M. Effect of dietary phytochemicals on cancer development. Int J Mol Med 1998; 1: 747-53.

[22] Daviglus ML, Dyer AR, Persky V, et al. Dietary betacarotene, vitamin C, and risk of prostate cancer: Results from the Western Electric Study. Epidemiology 1996; 7: 472-7. http://dx.doi.org/10.1097/00001648-199609000-00003

[23] Block G. Epidemiologic evidence regarding vitamin $C$ and cancer. Am J Clin Nutr 1991; 54(Suppl 6): 1310S-4S.
[24] Shibata A, Paganini-Hill A, Ross RK, Henderson BE. Intake of vegetables, fruits, beta-carotene, vitamin $C$ and vitamin supplements and cancer incidence among the elderly: a prospective study. Br J Cancer 1992; 66: 673-9.

http://dx.doi.org/10.1038/bjc.1992.336

[25] Khaw KT, Bingham S, Welch A, et al. Relation between plasma ascorbic acid and mortality in men and women in EPIC-Norfolk prospective study: a prospective population study. Lancet 2001; 357: 657-63

http://dx.doi.org/10.1016/S0140-6736(00)04128-3

[26] Maramag C, Menon M, Balaji KC, Reddy PG, Laxmanan S. Effect of vitamin $C$ on prostate cancer cells in vitro: effect on cell number, viability, and DNA synthesis. Prostate 1997; 32: 188-95. http://dx.doi.org/10.1002/(SICI)10970045(19970801)32:3<188::AID-PROS5>3.0.CO;2-H

[27] Willis $M$, Wians $F$. The role of nutrition in preventing prostate cancer: a review of the proposed mechanism of action of various dietary substances. Clinica Chimica Acta 2003; 330: 57-83.

http://dx.doi.org/10.1016/S0009-8981(03)00048-2

[28] Franceschi S, Bidoli E, La Vecchia C, et al. Tomatoes and risk of digestive-tract cancers. Int J Cancer 1994; 59: 181-4. http://dx.doi.org/10.1002/ijc.2910590207

[29] Gerster $\mathrm{H}$. The potential role of lycopene for human health. J Am College Nutr 1997; 16: 109-26.

[30] Rao AV, Fleshner N, Agarwal S. Serum and tissue lycopene and biomarkers of oxidation in prostate cancer patients: a case-control study. Nutr Cancer 1999; 33: 159-64. http://dx.doi.org/10.1207/S15327914NC330207

[31] Etminan M, Takkouche B, Caamano-Isorna F. The role of tomato products and lycopene in the prevention of prostate cancer: a meta-analysis of observational studies. Cancer Epidemiol Biomarkers Prev 2004; 13: 340-5.

[32] Basu A, Imrhan V. Tomatoes versus lycopene in oxidative stress and carcinogenesis: conclusions from clinical trials. Eur J Clin Nutr 2007: 61; 295-303. http://dx.doi.org/10.1038/sj.ejcn.1602510

[33] Kim HS, Bowen P, Chen L, et al. Effects of tomato sauce consumption on apoptotic cell death in prostate benign hyperplasia and carcinoma. Nutr Cancer 2003; 47: 40-7. http://dx.doi.org/10.1207/s15327914nc4701 5

[34] Grant W. An ecologic study of dietary links to prostate cancer. Altern Med Rev 1999; 4: 162-9.

[35] Gann PH, Ma J, Giovannucci E, et al. Lower prostate cancer risk in men with elevated plasma lycopene levels; results of a prospective analysis. Cancer Res 1999; 59: 1225-30.

[36] Bendich A, Olson JA. Biological action of carotenoids. FASEB J 1989; 3: 1927-32.

[37] Giovannucci E, Ascherio A, Rimm EB, et al. Intake of carotenoids and retinal in relation to risk of prostate cancer. $\mathrm{J}$ Nat Cancer Inst 1995; 87: 1767-76.

http://dx.doi.org/10.1093/jnci/87.23.1767

[38] Giovannucci E, Rimm EB, Liu Y, Stampfer MJ, Willett WC. A prospective study of tomato products, lycopene, and prostate cancer risk. J Natl Cancer Inst 2002; 94: 391-8. http://dx.doi.org/10.1093/jnci/94.5.391

[39] Sandmann G. Carotenoid biosynthesis in microorganisms and plants. Eur J Biochem 1994; 223: 7-24. http://dx.doi.org/10.1111/j.1432-1033.1994.tb18961.x

[40] Di Mascio P, Kaiser S, Sies H. Lycopene as the most efficient biological carotenoid singlet oxygen quencher. Arch Biochem Biophys 1989; 274: 532-8. http://dx.doi.org/10.1016/0003-9861(89)90467-0

[41] Siler U, Barella L, Spitzer V, et al. Lycopene and vitamin E interfere with autocrine/paracrine loops in the Dunning prostate cancer model. FASEB J 2004; 18: 1019-21. 
[42] Craig W. Phytochemicals: guardians of our health. J Am Diet Assoc 1997; 97: S199-204.

http://dx.doi.org/10.1016/S0002-8223(97)00765-7

[43] Rao CV, Rivenson A, Simi B, Reddy BS. Chemoprevention of colon carcinogenesis by dietary curcumin, a naturally occurring plant phenolic compound. Cancer Res 1995; 55: 259-66.

[44] Huang MT, Newmark HL, Frenkel K. Inhibitory effects of curcumin on tumorigenesis in mice. J Cell Biochem Suppl 1997; 27: 26-34.

http://dx.doi.org/10.1002/(SICI)1097-

4644(1997)27+<26::AID-JCB7>3.0.CO;2-3

[45] Hanif R, Qiao L, Shiff SJ, Rigas B. Curcumin, a natural plant phenolic food additive, inhibits cell proliferation and induces cell cycle changes in colon adenocarcinoma lines by a prostaglandin-independent pathway. J Lab Clin Med 1997; 130: $576-84$. http://dx.doi.org/10.1016/S0022-2143(97)90107-4

[46] Nagabhushan $M$ and Bhide S. Curcumin as an inhibitor of cancer. J Am Coll Nutr 1992; 11:192-8.

[47] Deeb D, Jiang H, Gao X, et al. Curcumin sensitizes prostate cancer cells to tumor necrosis factor-related apoptosisinducing ligand/Apo2L by inhibiting nuclear factor-kappa through suppression of 1 kappaBalpha phosphorylation. Mol Cancer Ther 2004; 3: 803-12.

[48] Dorai T, Dutcher JP, Dempster DW, Wiernik PH. Therapeutic potential of curcumin in prostate cancer-V: Interference with the osteomimetic properties of hormone refractory $\mathrm{C} 4-2 \mathrm{~B}$ prostate cancer cells. Prostate 2004; 60: 1-17. http://dx.doi.org/10.1002/pros.10359

[49] Chendil D, Ranga RS, Meigooni D, Sathishkumar S, Ahmed MM. Curcumin confers radio-sensitizing effect in prostate cancer cell line PC-3. Oncogene 2004; 26: 1599-607.

http://dx.doi.org/10.1038/sj.onc. 1207284

[50] Sharma RA, Gescher AJ, Steward WP. Curcumin: the story so far. Eur J Cancer 2005; 41: 1955-68.

http://dx.doi.org/10.1016/j.ejca.2005.05.009

[51] Yun TK. Update from Asia: Asian studies on cancer chemoprevention. Ann NY Acad Sci 1999; 889: 157-92. http://dx.doi.org/10.1111/j.1749-6632.1999.tb08734.x

[52] Saleem M, Adhami VM, Siddiqui IA, Mukhtar H. Tea beverage in chemoprevention of prostate cancer: a minireview. Nutr Cancer 2003; 47: 13-23.

http://dx.doi.org/10.1207/s15327914nc4701_2

[53] Jian L, Xie LP, Lee AH, Binns CW. Protective effect of green tea against prostate cancer: a case-control study in southeast China. Int J Cancer 2004; 108: 130-5. http://dx.doi.org/10.1002/ijc.11550

[54] Cao Y, Cao R. Angiogenesis inhibited by drinking tea. Nature 1999; 398: 381. http://dx.doi.org/10.1038/18793

[55] Liao S, Hiipakka R. Selective inhibition of steroid 5 alphareductase isozymes by tea epicatechin-3-gallate and epigallocatechin-3-gallate. Biochem Biophys Res 1995; 214: 833-8.

http://dx.doi.org/10.1006/bbrc.1995.2362

[56] Gupta S, Ahmad N, Mohan RR, Husain MM, Mukhtar H. Prostate cancer chemoprevention by green tea: in vitro and in vivo inhibition of testosterone-mediated induction of ornithine decarboxylase. Cancer Res 1999; 59: 2115-20.

[57] Kanwar J, Taskeen M, Mohammad I, et al. Recent advances on tea polyphenols. Front Biosci 2012; 4: 111-31.

[58] Yu HN, Yin JJ, Shen SR. Growth inhibition of prostate cancer cells by epigallocatechin gallate in the presence of CU2+. J Agric Food Chem 2004; 111: 462-6. http://dx.doi.org/10.1021/jf035057u

[59] Bhatia N, Agarwal R. Detrimental effect of cancer preventive phytochemicals silymarin, genistein, and epigallocatechin 3- gallate on epigenetic events in human prostate carcinoma DU145 cells. Prostate 2001; 46: 98-107.

http://dx.doi.org/10.1002/1097-0045(20010201)46:2<98::AIDPROS1013>3.0.CO;2-K

[60] Brusselmans K, De Schrijver E, Heyns W, Verhoeven G, Swinnen JV. Epigallocatechin-3-gallate is a potent natural inhibitor of fatty acid synthase intact cells and selectively induces apoptosis in prostate cancer. Int J Cancer 2003; 106: 856-62. http://dx.doi.org/10.1002/ijc.11317

[61] Nam S, Smith DM, Dou QP. Ester bond containing tea polyphenols potently inhibit proteasome activity in vitro and in vivo. J Biol Chem 2001; 276: 1322-30.

http://dx.doi.org/10.1074/jbc.M004209200

[62] Hussain T, Gupta S, Adhami VM, Mukhtar H. Green tea constituent epigallocatechin-3-gallate selectively inhibits COX-2 without affecting COX expression in human prostate carcinoma cells. Int J Cancer 2005; 113: 660-9. http://dx.doi.org/10.1002/ijc.20629

[63] Paschka AG, Butler R, Young CY. Induction of apoptosis in prostate cancer cell lines by the green tea component, $(-)$ epigallocatechin-3-gallate. Cancer Lett 1998; 130: 1-7. http://dx.doi.org/10.1016/S0304-3835(98)00084-6

[64] Stuart EC, Scandlyn MJ, Rosengren RJ. Role of epigallocatechingallate (EGCG) in the treatment of breast and prostate cancer. Life Sci 2006; 79: 2329-36.

http://dx.doi.org/10.1016/j.lfs.2006.07.036

[65] Jatoi A, Ellison N, Burch PA, et al. A phase II trial of green tea in the treatment of patients with androgen independent metastatic prostate carcinoma. Cancer 2003; 97: 1442-6. http://dx.doi.org/10.1002/cncr.11200

[66] Day N. Phyto-estrogens and hormonally dependent cancers. Pathol Biol 1994; 42: 1090.

[67] Sarkar F, Li Y. Soy isoflavones and cancer prevention. Cancer Invest 2003; 21: 744-57. http://dx.doi.org/10.1081/CNV-120023773

[68] Morton MS, Griffiths K, Blacklock N. The preventive role of diet in prostatic disease. Br J Urol 1996; 77: 481-93.

http://dx.doi.org/10.1046/j.1464-410X.1996.09361.x

[69] Lee MM, Gomez SL, Chang JS, et al. Soy and isoflavone consumption in relation to prostate cancer risk in China. Cancer Epidemiol Biomarkers Prev 2003; 12: 665-8.

[70] Sarwar G, McDonough F. Evaluation of protein digestibilitycorrected amino acid score method for assessing protein quality of foods. J Assoc Anal Chem 1990; 73: 346-56.

[71] Elias R, De Méo M, Vidal-Ollivier E, et al. Antimutagenic activity of some saponins isolated from Calendula officinalis L., C. arvensis L., and Hedera helix L. Mutangenesis 1990; 5: 327-31.

http://dx.doi.org/10.1093/mutage/5.4.327

[72] Baten A, Ullah A, Tomazic VJ, Shamsuddin AM. Inositophosphate-induced enhanced of natural killer cell activity correlates with tumor suppression. Carcinogenic 1989; 10: 1595-8.

http://dx.doi.org/10.1093/carcin/10.9.1595

[73] Adlercreutz $\mathrm{H}$, Mazur W. Phyto-oestrogens and Western diseases. Ann Med 1997; 29: 95-120.

[74] Evans BA, Griffiths K, Morton MS. Inhibition of 5 alphareductase in genital skin fibroblasts and prostate tissue by dietary lignans and isoflavinoids. J Endocrinol 1995; 147: 295-302. http://dx.doi.org/10.1677/joe.0.1470295

[75] Xu L, Ding Y, Catalona WJ, et al. MEK4 function, genistein treatment, and invasion of human prostate cancer cells. J Natl Cancer Inst 2009; 101: 1141-55.

http://dx.doi.org/10.1093/jnci/djp227

[76] Lakshman M, Xu L, Ananthanarayanan V, et al. Dietary genistein inhibits metastasis of human prostate cancer in mice. Cancer Res 2008; 68: 2024-32.

http://dx.doi.org/10.1158/0008-5472.CAN-07-1246 
[77] St Clair WH, Billings PC, Carew JA, et al. Suppression of dimethylhydrazine-induced carcinogenesis in mice by dietary addition of the Bowman-Birk Protease inhibitor. Cancer Res 1990; 50: 580-6.

[78] Knekt $\mathrm{P}$, Kumpulainen J, Jarvinen $\mathrm{R}$, et al. Flavonoid intake and risk of chronic disease. Am J Clin Nutr 2002; 76: 560-8.

[79] Leake A, Chrisholm GD, Busuttil A, Habib FK. Subcellular distribution of zinc in the benign and malignant human prostate: evidence for a direct zinc androgen interaction. Acta Endocrinol 1984; 105: 281-8

[80] Zaichick VY, Sviridova TV, Zaichick SV. Zinc concentration in human prostatic fluid. Normal, chronic prostatitis, adenoma, and cancer. Int Urol Nephrol 1996; 28: 687-94. http://dx.doi.org/10.1007/BF02552165

[81] Yu C, Tsai M. Fetal fetuin selectively induces apoptosis in cancer cell lines and shows anti-cancer activity in tumor animal models. Cancer Lett 2001; 166: 173-84. http://dx.doi.org/10.1016/S0304-3835(01)00417-7

[82] Ishii K, Usui S, Sugimura $\mathrm{Y}$, et al. Aminopeptidase $\mathrm{N}$ regulated by zinc in human prostate participates in tumor cell invasion. Int J Cancer 2001; 92: 49-54.

http://dx.doi.org/10.1002/1097-

0215(200102)9999:9999<::AID-IJC1161>3.0.CO;2-S

[83] Login IS, Thorner MO, MacLeod RM. Zinc may have a physiological role in regulating pituitary prolactin secretion. Neuroendocrinol 1983; 37: 317-20. http://dx.doi.org/10.1159/000123568

[84] Judd AM, Macleod RM, Login IS. Zinc acutely, selectively, and reversibly inhibits pituitary prolactin secretion. Brain Res 1984; 294: 190-2. http://dx.doi.org/10.1016/0006-8993(84)91330-1

[85] Farnsworth WE, Slaunwhite WR Jr, Sharma M, et al. Interaction of prolactin and testosterone in the human prostate. Urol Res 1981; 9: 79-88. http://dx.doi.org/10.1007/BF00256681

[86] Rashid SF, Moore JS, Walker E, et al. Synergistic growth inhibition of prostate cancer cells by 1 alpha Dihydroxyvitamin $\mathrm{D}(3)$ and its 19-norhexafluoride analogs in combination with either sodium butyrate or trichostatin $A$. Oncogene 2001; 20: 1860-72.

http://dx.doi.org/10.1038/sj.onc.1204269

[87] Hsu JY, Feldman D, McNeal JE, Peehl DM. Reduced 1 alpha-hydroxylase activity in human prostate cancer cells correlates with decreased susceptibility to 25 -hydroxyvitamin D3-induced growth inhibition. Cancer Res 2001; 61: 2852-6.

[88] Zhao X, Feldman D. The role of vitamin $D$ in prostate cancer. Steroid 2001; 66: 293-300. http://dx.doi.org/10.1016/S0039-128X(00)00164-1

[89] Yang E, Burnstein K. Vitamin D inhibits $G 1$ to $S$ progression in LNCa prostate cancer cells through p27 Kip1 stabilization and Cdk2 mislocalization to the cytoplasm. J Biol Chem 2003; 278: 46862-8.

http://dx.doi.org/10.1074/jbc.M306340200

[90] LaMonica CS, Weigel NL. Vitamin D and Prostate Cancer. Exp Biol Med 2004; 229: 277-84.

[91] Jacobs ET, Giuliano AR, Martínez ME, et al. Plasma levels of 25-hydroxyvitain $D, 1,25$-dihydroxyvitain $D$ and the risk of prostate cancer. J Steroid Biochem Mol Biol 2004; 89-90: 533-7.

http://dx.doi.org/10.1016/j.jsbmb.2004.03.063

[92] Bao BY, Ting HJ, Hsu JW, Lee YF. Protective role of 1 alpha, 25-dihydroxyvitamin D3 [vitamin D3] against oxidative stress in nonmalignant human prostate epithelial cells. Int $\mathrm{J}$ Cancer 2008; 122: 2699-706. http://dx.doi.org/10.1002/ijc.23460

[93] Kumar NB, Cantor A, Allen K, et al. The specific role of isoflavones in reducing prostate cancer risk. Prostate 2004; 59: 141-7.

http://dx.doi.org/10.1002/pros.10362
[94] Moline B, Georgel P. Genetic and epigenetic regulations of prostate cancer by genistein. Drug News Perspect 2009; 22: 247-54.

http://dx.doi.org/10.1358/dnp.2009.22.5.1378633

[95] Fotsis T, Pepper M, Adlercreutz H, et al. Genistein, a dietaryderived inhibitor of in vitro angiogenesis. Proc Natl Acad Sci USA 1993; 90: 2690-4.

http://dx.doi.org/10.1073/pnas.90.7.2690

[96] Kyle E, Neckers L, Takimoto C, Curt G, Bergan R. Genisteininduced apoptosis of prostate cancer cells is preceded by a specific decrease in focal adhesion kinase activity. Mol Pharmacol 1997; 51: 193-200.

[97] Peterson G, Barnes S. Genistein and biochanin A inhibit the growth of human prostate cancer cells but not epidermal growth factor receptor tyrosine autophosphorylation. Prostate 1993; 22: 335-45.

http://dx.doi.org/10.1002/pros.2990220408

[98] Davis JN, Kucuk O, Djuric Z, Sarkar FH. Soy isoflavone supplementation in healthy men prevents NF-kappaB activation by TNF-alpha in blood lymphocytes. Free Radic Biol Med 2001; 30: 1293-302.

http://dx.doi.org/10.1016/S0891-5849(01)00535-4

[99] Shen JC, Klein RD, Wei $Q$, et al. Low-dose genistein cyclindependent kinase inhibitors a $\mathrm{G}(1)$ cell cycle arrest in human prostate cancer cells. Mol Carcinog 2000; 29: 92-102. http://dx.doi.org/10.1002/1098-2744(200010)29:2<92::AIDMC6>3.0.CO;2-Q

[100] Yu L, Blackburn GL, Zhou JR. Genistein and daidzein down regulate prostate androgen-regulated transcript-1(PART-1) gene expression induced by dihydrotestosterone in human prostate LNCaP cancer cells. J Nutr 2003; 133: 389-92.

[101] National Research Council Staff. Diet and Health: Implications for Reducing Chronic Disease Risk. Washington, DC: National Academy of Education 1989: 376-9.

[102] Salonen JT, Salonen R, Lappeteläinen R, et al. Risk of cancer in relation to serum concentrations of selenium and vitamins $\mathrm{A}$ and $\mathrm{E}$ : matched case-control analysis of prospective data. Br Med J 1985; 290: 417-20. http://dx.doi.org/10.1136/bmj.290.6466.417

[103] Webber MM, Perez-Ripoll EA, James GT. Inhibitory effects of selenium on the growth of DU-145 human prostate carcinoma cell in vitro. Biochem Biophys Res Comm 1985; 130: 603-9. http://dx.doi.org/10.1016/0006-291X(85)90459-0

[104] Jiang C, Wang Z, Ganther H, Lu J. Caspases as key executors of methyl selenium-induced apoptosis (anoikis) of DU-145 prostate cancer cells. Cancer Res 2001; 61: 306270.

[105] Webber M. Selenium prevents the growth stimulatory effects of cadmium on human prostatic epithelium. Biochem Biophys Res Commun 1985; 127: 871-7.

http://dx.doi.org/10.1016/S0006-291X(85)80024-3

[106] Ghosh J. Rapid induction of apoptosis in prostate cancer by selenium: reversal by metabolites of arachidonic 5lipoxygenase. Biochem Biophys Res Commun 2004; 12: 624-35.

http://dx.doi.org/10.1016/j.bbrc.2004.01.100

[107] Zu K, Ip C. Synergy between selenium and vitamin E in apoptosis induction is associated with activation of distinctive initiator caspases in human prostate cancer cells. Cancer Res 2003; 63: 6988-95.

[108] Combs GF Jr, Clark LC, Turnbull BW. Reduction of cancer risk with an oral supplement of selenium. Biomed Environ Sci 1997; 10: 227-34.

[109] Bleys J, Navas-Acien A, Guallar E. Serum selenium levels and all-cause, cancer, and cardiovascular mortality among US adults. Arch Intern Med 2008;168: 404-10. http://dx.doi.org/10.1001/archinternmed.2007.74

[110] Hartman TJ, Albanes D, Pietinen P, et al. The association between baseline vitamin E, selenium, and prostate cancer 
in the alpha-tocopherol, beta-carotene cancer prevention study. Cancer Epidemiol Biomarkers Prev 1998; 7: 335-40.

[111] Heinonen OP, Albanes D, Virtamo J, et al. Prostate cancer and supplementation with alpha-tocopherol and betacarotene: incidence and mortality in a controlled trial. J Natl Cancer Inst 1998; 90: 440-6.

http://dx.doi.org/10.1093/jnci/90.6.440

[112] Virtamo J, Pietinen P, Huttunen JK, et al. Incidence of cancer and mortality following alpha-tocopherol and beta-carotene supplementation: postintervention follow-up. JAMA 2003; 290: 476-85.

http://dx.doi.org/10.1001/jama.290.4.476

[113] Peters U, Littman AJ, Kristal AR, et al. Vitamin E and selenium supplementation and risk of prostate cancer in the Vitamins and lifestyle (VITAL) study cohort. Cancer Causes Control 2008; 19: 75-87.

http://dx.doi.org/10.1007/s10552-007-9072-y

[114] Pastori M, Pfander H, Boscoboinik D, Azzi A. Lycopene in association with alpha-tocopherol inhibits at physiological concentrations proliferation of prostate carcinoma cells. Biochem Biophys Res Comm 1998; 250: 582-5.

http://dx.doi.org/10.1006/bbrc.1998.9351

[115] Wright ME, Weinstein SJ, Lawson KA, et al. Supplemental and dietary vitamin $E$ intakes and risk of prostate cancer in a large prospective study. Cancer Epidemiol Biomarkers Prev 2007; 16: 112.

http://dx.doi.org/10.1158/1055-9965.EPI-06-1071

[116] Thompson T, Wilding G. Androgen antagonist activity by the antioxidant moiety of vitamin E, 2, 2,5,7,8-pentamethyl-6chromanol in human prostate carcinoma cells. Mol Cancer Ther 2003; 2: 797-803.

[117] Carilla E, Briley M, Fauran F, Sultan C, Duvilliers C. Binding of Permixon, a new treatment for prostatic benign hyperplasia to the cytosolic androgen receptor in the rat prostate. J Steroid Biochem 1984; 20: 521-3.

http://dx.doi.org/10.1016/0022-4731(84)90265-6

[118] Sultan C, Terraza A, Devillier C, et al. Inhibition of androgen metabolism and binding by a liposteric extract of Serenoa repens B in human foreskin fibroblasts. J Steroid Biochem 1984; 20: 515-9.

http://dx.doi.org/10.1016/0022-4731(84)90264-4

[119] Crimi A, Russo A. Extract of Serenoa repens for the treatment of the functional disturbances of prostate hypertrophy. Med Praxis 1983; 4: 47-51.

[120] Wilt TJ, Ishani A, Rutks I, MacDonald R. Phytotherapy for benign prostatic hyperplasia. Public Health Nutr 2000; 3: 459-72.

http://dx.doi.org/10.1017/S1368980000000549

[121] Goldmann WH, Sharma AL, Currier SJ, et al. Saw palmetto berry extract inhibits cell growth: Cox-2 expression in prostatic cancer cells. Cell Biol Int 2001; 25: 1117-24. http://dx.doi.org/10.1006/cbir.2001.0779

[122] Thelen $P$, Jarry $H$, Ringert $R H$, Wuttke W. Silibinin downregulates prostate epithelium-dependent Ets transcription factor in LNCaP prostate cancer cells. Planta Med 2004; 70: 397-400. http://dx.doi.org/10.1055/s-2004-818965

[123] Liu WK, Xu SX, Che CT. Anti-proliferative effect of ginseng saponins on human prostate cancer cell line. Life Sci 2000; 67: 1297-1306.

http://dx.doi.org/10.1016/S0024-3205(00)00720-7

[124] Woo MH, Chung SO, Kim DH. Cis-Annonacin and $(2,4)$-cisand trans-isoannonacins:cytotoxic monotetrahydrofuran annonaceous acetogenins from the seeds of Annona cherimolia. Arch Pharm Res 1999; 22 : 524-8.

http://dx.doi.org/10.1007/BF02979164

[125] Kim DH, Ma ES, Suk KD, et al. Annomolin and annocherimolin, new cytotoxic annonaceous acetogenins from Annona cherimolia seeds. J Nat Prod 2001; 64: 502-6. http://dx.doi.org/10.1021/np000335u
[126] Santa María Margalef A, Paciucci Barzanti R, Reventós Puigjaner J, Morote Robles J. Antimitogenic effect of pygeum africanum extract on human prostatic cancer cell lines and explants form benign prostatic hyperplasia. Arch Esp Urol 2003; 56: 369-78. [Spanish]

[127] Shenouda NS, Sakla MS, Newton LG, et al. Phytosterol Pygeum africanum regulates prostate cancer in vitro and in vivo. Endocrine 2007; 31: 72-81.

http://dx.doi.org/10.1007/s12020-007-0014-y

[128] Colpi G, Farina U. Study of the activity of chloroformic extract of Pygeum africanum bark in the treatment of urethral obstructive syndrome caused by non-cancerous prostapathy. Urologia 1976; 43: 441-8.

[129] Lucchetta G, Weill A, Becker N, et al. Reactivation from the prostatic gland in cases of reduced fertility. Urol Int 1984; 39: 222-4. http://dx.doi.org/10.1159/000280980

[130] Carani C, Salvioli V, Scuteri A, et al. Urological and sexual evaluation of treatment of benign prostatic disease using Pygeum africanum at high dose. Arch Ital Urol Nefrol Androl 1991; 63: 341-5. [Italian]

[131] Efferth T, Dunstan H, Sauerbrey A, Miyachi H, Chitambar CR. Antimalarial artesunate is also active against cancer. Int J Oncol 2001; 18 : 767-73.

[132] Lai H, Singh N. Artemisinin and Cancer. Int J Oncol 2001; 18: 767-72.

[133] Chyou PH, Nomura AM, Stemmermann GN, et al. A prospective study of alcohol, diet, and other lifestyle factors in relation to obstructive uropathy. Prostate 1993; 22: 253-64. http://dx.doi.org/10.1002/pros.2990220308

[134] Christudoss P, Selvakumar R, Fleming JJ, Gopalakrishnan G. Zinc status of patients with benign prostatic hyperplasia and prostate carcinoma. Indian J Urol 2011; 27: 14-8. http://dx.doi.org/10.4103/0970-1591.78405

[135] Gerber G, Fitzpatrick J. Role of a lipido-sterolic extract of Serenoa repents in the management of lower urinary tract symptoms associated with benign prostate hyperplasia B. J Urol Int 2004; 94: 338-44.

http://dx.doi.org/10.1111/j.1464-410X.2004.04962.x

[136] Comhaire E, Mohmoud A. Preventing diseases of the prostate in the elderly using hormones and nutraceuticals. Aging Male 2004; 7 : 155-69.

http://dx.doi.org/10.1080/13685530412331284722

[137] Berges RR, Windeler J, Trampisch HJ, et al. Randomized, place-controlled, double-blind clinical trial of beta-sitosterol in patients with benign prostatic hyperplasia. Lancet 1995; 345: 1529-32.

http://dx.doi.org/10.1016/S0140-6736(95)91085-9

[138] Miller GJ, Brawer MK, Sakr WA, Thrasher JB, Townsend R. Prostate Cancer: Serum and Tissue Markers. Rev Urol 2001; 3(S2): S11-S19.

[139] Hayes RB, Ziegler RG, Gridley G, et al. Dietary factors and risks for prostate cancer among blacks and whites in the United States. Cancer Epidemiol Biomarkers Prev 1999; 8: 25-34.

[140] Damber J, Aus G. Prostate cancer. Lancet 2008; 371: 171021. http://dx.doi.org/10.1016/S0140-6736(08)60729-1

[141] Jemal A, Thomas A, Murray T, Thun M. Cancer Statistics 2002. CA Cancer Clin 2002; 52: 23-47. http://dx.doi.org/10.3322/canjclin.52.1.23

[142] Longo D. Approach to the patient with cancer. In: Fauci AS, Wilson JD, Martin JB, et al, eds. Harrison's Principles of Internal Medicine. $14^{\text {th. }}$ ed. New York, NY: McGraw-Hill; 1998.

[143] American Cancer Society. Cancer Facts and Figures 2012. Atlanta:American Cancer Society; 2012 http://www.cancer.org/ content/@epidemiologysurveilance 031941.pdf [Accessed: May 23, 2012.] /document/acspc- 
[144] Schwartz G, Hulka B. Is vitamin D deficiency a risk factor for prostate cancer? Anticancer Res 1990; 10: 1307-11.

[145] Rebbeck TR, Walker AH, Zeigler-Johnson C, et al. Association of HPC/ELAC2 genetypes and prostate cancer. Am J Hum Genet 2000; 67: 1014-9.

http://dx.doi.org/10.1086/303096

[146] Stanford J, Sabacan LP, Noonan EA, et al. Association of HPC2/ELAC2 polymorphisms with risk of prostate cancer in a population-based study. Cancer Epid Biomarkers Prev 2003; 12: 876-81.

[147] Wang L, McDonnell SK, Elkins DA, et al. Role of HPC2/ELAC2 in hereditary prostate cancer. Cancer Res 2001; 61: 6494-9.

[148] Meitz J, Edwards SM, Easton DF, et al. HPC2/ELAC2 polymorphisms and prostate cancer risk: analysis by age of onset of disease. Br J Cancer 2002; 87: 905-8. http://dx.doi.org/10.1038/sj.bjc.6600564

[149] Ishii K, Usui S, Sugimura $\mathrm{Y}$, et al. Aminopeptidase $\mathrm{N}$ regulated by zinc in human prostate participates in tumor cell invasion. Int J Cancer 2001; 92: 49-54.

http://dx.doi.org/10.1002/10970215(200102)9999:9999<::AID-IJC1161>3.0.CO:2-S

[150] Giovannucci E, Rimm EB, Stampfer MJ, Colditz GA, Willett WC. Height, weight, and risk of prostate cancer. Cancer Epidemiol Biomarkers 1997; 6: 557-63.

[151] Grant J. Proper use and recognized role of TPN in the cancer patient. Nutrition 1990; 6: 6S-7S.

[152] Agency for Toxic Substances and Disease Registry (ATSDR). Toxicological Profile for Cadmium. Atlanta, GA: U.S. Department of Health and Human Services, Public Health Service. 2008.

[153] Kappas A, Anderson KE, Conney AH, et al. Nutritionendocrine interactions. Induction of reciprocal changes in the delta-5-alpha-reduction of testosterone and the cytochrome P-450-dependent oxidation of estradiol by dietary macronutrients in man. Proc Natl Acad Sci USA 1983; 80: 7646-9.

http://dx.doi.org/10.1073/pnas.80.24.7646

[154] Andriole G, Bruchovsky N, Chung LW, et al. Dihydrotestosterone and the prostate: the scientific rationale for 5-alpha-reductase inhibitors in the treatment of benign prostatic hyperplasia. J Urol 2004; 172: 1399-403. http://dx.doi.org/10.1097/01.ju.0000139539.94828.29

[155] Hays B. Hormonal Imbalances. In: D Jones, ed. 2010. Textbook of Functional Medicine. Jones D, ed. 2010. Gig Harbor, WA: The Institute for Functional Medicine, p238.

[156] Miller G. Vitamin D and Prostate Cancer: Biologic Interactions and Clinical Potentials. Cancer Metastasis Rev 1999; 17: 353-60.

http://dx.doi.org/10.1023/A:1006102124548

[157] Bosland M. The role of steroid hormones in prostate carcinogenesis. J Natl Cancer Inst Monogr 2000; 27: 39-66. http://dx.doi.org/10.1093/oxfordjournals.jncimonographs.a02 $\underline{4244}$

[158] Leav I, Lau KM, Adams JY, et al. Comparative studies of the estrogen receptors beta and alpha and the androgen receptor in normal human prostate glands, dysplasia, and in primary and metastatic carcinoma. Am J Pathol 2001; 159: 79-93.

http://dx.doi.org/10.1016/S0002-9440(10)61676-8

[159] Platz E, Giovannucci E. The epidemiology of sex steroid hormones and their signaling and metabolic pathways in the etiology of prostate cancer. J Steroid Biochem Mol Biol 2004; 92: 237-53.

http://dx.doi.org/10.1016/j.jsbmb.2004.10.002

[160] Margel D, Fleshner N. Oral contraceptive use is associated with prostate cancer: an ecological study. BMJ Open 2011; 1: e000311

http://dx.doi.org/10.1136/bmjopen-2011-000311

[161] Roddam AW, Allen NE, Appleby P, Key TJ. Endogenous Hormones and Prostate Cancer Collaborative Group. Endogenous sex hormones and prostate cancer: a collaborative analysis of 18 prospective studies. J Natl Cancer Inst 2008; 100: 170-83. http://dx.doi.org/10.1093/jnci/djm323

[162] Tang L, Yao S, Till C, et al. Repeat polymorphisms in estrogen metabolism genes and prostate cancer risk: results from the Prostate Cancer Prevention Trial. Carcinogenesis 2011; 32: 1500-6. http://dx.doi.org/10.1093/carcin/bgr139

[163] Faguet G. The War on Cancer: An Anatomy of Failure, A Blueprint for the Future. Springer. The Netherlands 2005. p. 17.

[164] Miller G. Vitamin D and Prostate Cancer: Biologic Interactions and Clinical Potentials. Cancer Metastasis Rev 1999; 17: 353-60. http://dx.doi.org/10.1023/A:1006102124548

[165] Botella-Carretero J, Alvarez-Blasco F, Villafruela JJ, et al. Vitamin D deficiency is associated with the metabolic syndrome in morbid obesity. Clin Nutr 2007; 26: 573-80. http://dx.doi.org/10.1016/j.clnu.2007.05.009

[166] Haseman MK, Reed NL, Rosenthal SA. Monoclonal antibody imaging of occult prostate cancer in patients with elevated prostate-specific antigen: positron emission tomography and biopsy correlation. Clin Nucl Med 1996; 21: 703-13.

http://dx.doi.org/10.1097/00003072-199609000-00007

[167] Mitterberger M, Aigner F, Horninger W, et al. Comparative efficiency of contrast-enhanced colour Doppler ultrasound targeted versus systematic biopsy for prostate cancer detection. Eur Radiol 2010; 20: 2701-6.

\section{http://dx.doi.org/10.1007/s00330-010-1860-1}

[168] De Zordo T, Ladurner M, Horninger W, et al. New ultrasound technologies for the diagnosis of prostate cancer. Radiologe 2011; 51: 930-6. [German] http://dx.doi.org/10.1007/s00117-011-2178-y

[169] Bree R. The role of color Doppler and staging biopsies in prostate cancer detection. Urology 1997; 49: 31-4. http://dx.doi.org/10.1016/S0090-4295(97)00166-0

[170] Tamburri P. Prostate cancer risk assessment: A qualitative approach. NDNR 2007; 3: 4-5.

[171] Argile JM. Cancer-associated malnutrition. Eur J Oncol Nurs 2005; 9(Suppl 2): S39-S50.

http://dx.doi.org/10.1016/j.ejon.2005.09.006

Received on 25-07-2012

Accepted on 26-08-2012

Published on 19-09-2012

\section{DOI: http://dx.doi.org/10.6000/1927-3037/2012.01.03.06}

(c) 2012 Steve Yap; Licensee Lifescience Global.

This is an open access article licensed under the terms of the Creative Commons Attribution Non-Commercial License (http://creativecommons.org/licenses/by-nc/3.0/) which permits unrestricted, non-commercial use, distribution and reproduction in any medium, provided the work is properly cited. 